\title{
When a Woman Thinks Alone: Rethinking Mexi- can History through Women and Faith
}

\author{
Jean Lauer
}

What else is woman but a foe to friendship, an unescapable punishment, a necessary evil, a natural temptation, a desirable calamity, a domestic danger, a delectable detriment, an evil of nature, painted with fair colours! [...] And Seneca says in his Tragedies: A woman either loves or hates; there is no third grade. And the tears of a woman are a deception, for they may spring from true grief, or they may be a snare. When a woman thinks alone, she thinks evil.

- The Malleus Maleficarum ${ }^{1}$

As colonies and then countries, the emergent Latin America produced many documents of its formation from the perspective of the colonizers. As the Old World sought to understand and organize the New, the Roman Catholic Church and its Inquisitorial agents worked to enforce holy teachings by means of trial and punishment. ${ }^{2}$ Out of these endeavors, and in dialogue with Rome's attempt to standardize its dogma, a system developed, albeit unevenly, to identify true Christians from heretics. In societies where women were virtually invisible, kept to domestic service, very few of them appear in official documents. Yet, there are cases where women become visible in records kept by the State and/or the Church, including the trials of the Inquisition. Although many records still exist, in the course of history, experiences of those persecuted in the name of the Holy Inquisition and establishment of the Spanish Crown, have been minimized if not denied entirely behind the rhetoric of "official" histories of the formation of the Mexican nation. Not surpris-

Jean Lauer is a PhD Candidate in the Department of Radio, Television, and Film at the University of Texas at Austin. She has previously published "Esmeralda Comes By Night as Postmodern Parody" in Interdisciplinary Humanities, and a book chapter co-authored with Rochelle Rodrigo, entitled "Resident Franchise: Theorizing the SF Genre, Conglomerations, and the Future of Synergy," is forthcoming in The Games SF Plays. 
ingly, the official histories' genesis and maintenance are centered largely in two spheres: the Church's or religious strains on one hand and the government or secular purview on the other.

To the extent that official histories are recognized and maintained through institutions and people, they provide a means to organize the past and come to terms with the ways that events shape the present. The fact that certain histories take priority over others in Mexico is not unusual in and of itself. As Michel-Rolph Trouillot so eloquently argues in Silencing the Past: Power and the Production of History, every history has a history, regardless of the place of its origin. Historical facts are selected and arranged by interested parties in order to inscribe official memory and relationships with the past with value. Certain facts have more relevance at certain times than others. ${ }^{3}$ From this perspective, "missing" or otherwise underrepresented versions of the past have value in that their recollections provide the opportunity to examine the processes that have inscribed official histories. To push this further, unofficial histories, or official histories that are collectively buried, may be engaged to destabilize the surface sheen of that which dominant versions would hold as truth.

This essay questions the stability of official versions of national identity formation in Mexico is in question, as well as the ways those versions purport to organize social participation. Through at times very different mechanisms, both the Church and the State have propagated their own myths of origin. Significantly, these two histories are in conflict with each other, even as they coexist tenuously in presentday Mexico. However, they share the common goal of erasing the history of the Inquisitorial process on the subjugation of the peoples of the New World and in the formation of the nation. While this is only one method of drawing on a missing history (and surely only one of these sorts of histories), the goal is to illustrate both the power of official histories to propagate erasure of the past, as well as the power of the past to reappear and destabilize the structures that seek to contain it. Here, I focus on cinematic representations that recall the formation of Mexico, with the aim of revealing a part of that formation that is elided by official versions of history. By recalling a past that is negated by more recent versions of history, such representations serve to destabilize the dominant versions of both the secular and religious accounts of nation formation. Perhaps most interestingly, by returning to a past that precedes the two semi-divergent histories (religious vs. secular), a history emerges in which Church and State complicity enabled and even defined the mechanisms of conquest in the young nation. In the end, it is in recognizing instances where the past penetrates the present that the official history of history loses, if only for a moment, its apparent impenetrability and the inherent contradictions within it may be embraced.

The representations that this argument mobilizes towards a historical intervention are those between women and their priest-confessors. When considered in particular relational contexts, these women's cases foreground a history of dismissal of women's improprieties within society. While recognizing that the scope of the Inquisition through the present-day church-congregant relationship is exceedingly complex, this project focuses on representations of women in contemporary 
contexts whose interactions with priests recall certain aspects of the Inquisitorial process. A fuller understanding of women's roles in developing a pragmatic approach to survival in contemporary Mexican society requires just such a historical reconnection, if for no other reason than that Church and State rhetoric (and even much critical discourse) have worked so diligently to erase the procedures through which Spain forged its presence in the New World. The films Santitos (Dir. Alejandro Springall, 1998) and The Crime of Padre Amaro (Dir. Carlos Carrera, 2003) provide two different yet complimentary examples of women in particular relation to her confessor-priest, namely in continual negotiation of her own self-determination and social agency. She is a woman who is at times punished for straying too far from the teachings of the Church, but who continually returns to seek comfort there, and/or who is called on by a priest at times when he needs a particular brand of knowledge not available within the confines of Church teaching. Ultimately, these representations function to articulate a history of resistance to Church and State rhetoric, which in turn informs possible critiques and responses to current changes within those Mexican institutions.

\section{Dionisia and Esperanza: Women and "The Faith"/Women and Faith}

Although there are more examples available - hence the interest in exploring this cultural expression - the present argument focuses on two contemporary Mexican films: Santitos (1998) and The Crime of Padre Amaro (2003). They are very different films; however, together they illustrate the traits described above: women who exist in a give-and-take with the institution of the Church, as mediated through their priest. Santitos is a relatively light-hearted film, even though it opens shortly after Esperanza's daughter Blanca has died suddenly, from a mysterious virus following a tonsillectomy. Due to the nature of the infection, the casket is sealed and Esperanza never has visual confirmation that her daughter is, indeed, dead. The day after the funeral, she has a vision of St. Jude, who appears to her in the glass of the oven door and tells her, "Whoever told you your daughter died of this unknown disease, lied to you." 4

Understandably, this sends Esperanza on a mission to find her daughter, and the journey and eventual acceptance of her daughter's death provide the spine of the film's storyline. The Crime of Padre Amaro, as the title hints, is much darker in tone, working as a commentary on the state of the priesthood and the Church's role in civil life. Padre Amaro, a young idealistic priest, arrives to work at a small parish church and falls into corruption, including seducing the young parishioner Amelia. Her pregnancy and its resolution shape approximately the latter third of the film's narrative. Amelia's confessional and amorous relationship with Padre Amaro aside, with its own echoes in representation throughout Latin America, of note here is Padre Amaro's relationship with the older woman Dionisia. Dionisia appears briefly throughout the story, but it is to her that Padre Amaro turns when he is in trouble.

Although it is much bleaker overall than Santitos, Padre Amaro is an excellent starting point for this discussion as the character of Dionisia clearly fits the part of the hechicera or woman who practices healing rituals blended from native and other traditions. The aim of the Conquest to rid the New World of idolatry actually 
resulted in syncretic religions practices rather than uniform Catholicism (e.g., Gruzinski 59-60). Images and practices mingled, although the more overt aspects of native cultures were pushed underground. As discussed later, they were often maintained by women who still practiced amongst themselves the rituals that they believed kept them safe or otherwise helped them survive under Catholic rule. In Padre Amaro, Dionisia appears to be a peripheral character at first, not interacting directly with the main storylines. She is introduced in church, at prayer and singing by herself, when Padre Amaro arrives for his assignment. One day at mass she takes her communion host and surreptitiously spits it out into her purse (not eating it). At home later, she offers it to one of her cats that is apparently ill, calling it "medicine." Dionisia's home is cluttered with objects, many of them baby dolls adorned, decorated, or even mutilated. These are mixed in with other objects and pictures of direct religious significance. The arrangements, while largely disturbing, were obviously very painstakingly prepared. Hence, Dionisia is first introduced in the church as a devout and habitual congregant; however, she is soon established as transgressing or subverting aspects of Catholic religion for her own purpose. While believing in the power of communion, or in Jesus or the saints, her applications would not be approved within the confines of the Church.

Dionisia's outsider status in the parish is quickly demonstrated. Although the narrative progression establishes her as trying to use her beliefs to help people, even heal them, her behavior is not received well by other parishioners. One day in mass, during Padre Amaro's sermon, Dionisia at first agrees with the preached message. She interjects, "He's right," as people around her turn to "shh" her. This is relatively undisruptive, as Padre Amaro does not seem to notice. However, as the sermon continues, and Padre Amaro preaches forgiveness towards a member of the community who has defamed the church, Dionisia becomes more and more agitated. Finally, one of Dionisia's outbursts causes a parishioner to shout, "Silence!" To this, Dionisia responds, "Heretics! You're a bunch of heretics!" This escalates until there is a sharp "Dionisia!" from Padre Amaro, who is shot in close, tight framing. The reverse shot of Dionisia shows her, apparently quieted, moping in her seat. The next shot of Padre Amaro just shows him looking out at Dionisia for a couple seconds, with dead silence in the church. Then the silence is shattered as the camera returns to show Dionisia singing the hymn "Reine Jesús por siempre, reine su corazón...." Joined by another women sitting next to her, they continue to sing as the camera shows Padre Amaro staring, wordless. The two women have the last words of the scene and effectively silence the priest who had tried to silence Dionisia; by singing a liturgical piece, they momentarily confound attempts to keep Dionisia from speaking her mind in Church. Presumably, although it is not shown, that subversion of power would revert to Padre Amaro, as the rest of the mass still remained. Yet the fact that Dionisia so clearly disrupts the flow of the service and has the upper hand for a moment stands out from the rest of the film's women characters who do not take such steps to question priestly authority.

Finally, Dionisia's character illustrates how women's negotiated relationship within the institutions around them are often only as invisible as those in power consider it to be: it is Padre Amaro himself who seeks out Dionisia's experience when he is in 
need. After Amelia and he try to resolve her pregnancy through other means, Padre Amaro goes to visit Dionisia. Their conversation begins as Padre Amaro steps into Dionisia's home:

PADREAMARO. Dionisia?

DIONISIA. What a surprise! What an honor! Come in, Father dear come in. ${ }^{5}[. .$.$] Sit down, Father.$

PA. I'm in a hurry.

D. Yes. And how is the little girl? Happy.

PA. Listen I heard in confession that you know a doctor. A doctor, I don't know. ${ }^{6}$ One of those who does...

D. Does what, Father?

PA. Brings children into the world. And also...

D. [as she crosses herself] Mother of God! The girl is pregnant?

PA. No.

Padre Amaro is clearly uncomfortable throughout, while Dionisia continually moves closer to him, staring at him intently, apparently trying to figure him out. After he says "No," she moves even closer to him and says:

D. What you want is an abortion, Father.

PA. [as he hands Dionisia money] I don't know if this is enough.

D. No, it takes a lot more. But don't worry. We'll settle up later.

First let me see.

PA. Yes.

D. I'll let you know in time. God bless you, Father.

PA. Yes.

In a rather impressive reversal of confessor roles, it is Dionisia who interrogates the priest to uncover the truth - a woman associated with practicing folk rituals and whose home is decorated with her version of the saints in a very eclectic altar. Then, once she has pulls the truth out of the priest, she is the one who gives him the blessing. He is left speechless and at her mercy.

For a time, Dionisia exercises some control over Padre Amaro's situation, in part because her outsider status allows her access to places where "respectable" people would not go, namely an abortion clinic. Rules of society and Church forbid abortions, yet Dionisia appears to privilege practical action over dogma and over laws. There is no question raised on her part of the morality of abortion; as in other parts of her life, she acts according to her own logic of how to remedy the situation. As a woman, Dionisia can certainly be expected to understand what would happen to Amelia should her pregnancy be discovered. Perhaps with that in mind, and because the rules of Church and State do not legally permit the necessary steps, Dionisia does not hesitate to transgress those laws to aid people she sees in need. However, as might be expected considering the society in which they live, Dionisia is only granted overt narrative agency for a short time. By the end of the film, Amelia has died from a botched abortion, and Padre Amaro has propagated a lie about the whole situation, leaving himself blameless in the eyes of the congregation. The one person who knows exactly what happened, namely Dionisia, is effectively silenced and complicit in the lie, for who is going to take her word over that of Padre Amaro? ${ }^{7}$ Because of the part she played, Dionisia also cannot denounce Padre Amaro and 
remain within the protection of the Church herself, something to which she clings throughout the film. In this case, the Church has mitigated the contestation of its power. However, the audience knows that a power inversion existed, centered in an intimate priest-congregant relationship, and focused on a woman who knows when to keep to her practices private and when to transgress more openly the norms of conduct propagated by those in power.

The other example, from the comedic/melodramatic film Santitos, also illustrates a woman's intimate relationship with the Church and to her priest-confessor. This time, it is Esperanza's compulsion to seek out Father Salvador and to check her actions against his advice that drives much of the story. Unlike Dionisia, Esperanza is the protagonist of the film, which begins with her seeking out confession. Like Dionisia, the audience's first introduction to the character is in church. In fact, for the first half-hour of the movie, the narrative is built entirely with flashbacks based on Esperanza's "confessions," with the exception of one short scene and one short sequence. In the confessional Esperanza often seeks more advice than forgiveness, however, a fact that often troubles the priest. ${ }^{8}$ Interestingly, when Father Salvador does tell Esperanza how to proceed, if it does not meet what she wants, she quickly expresses frustration. For example, when she asks if she can tell anyone about St. Jude's message, and Father Salvador says "No," she becomes angry. Father Salvador is clear that he does not want her to tell anyone, not even her best friend, Soledad. Esperanza agrees in the confessional, but then goes straight home to tell Soledad, who of course thinks the grieving mother is crazy.

A second apparition sends Esperanza off to "confession" again, but it is the third apparition and subsequent confession that sets the stage for Esperanza to truly begin the mission on her own. Before she sets out, though, she has to visit Father Salvador and run her thoughts by him. By this point, Esperanza is convinced that her daughter has been sold into prostitution, and her efforts to find her are along those lines. Esperanza has been working in a local sex "hotel" and cleaning the sheets, searching for Blanca. In confession she says:

ESPERANZA. But not a trace of Blanca. I'd smell the sheets, but never the scent of Blanca.

FATHER SALVADOR. For God's sake, daughter!

E. I want to confess on her behalf. Forgive her. She must not be able to come close to a church.

FS. You know that I can't absolve through third party confessions.

E. Don't be a pain, Father! What have you got to lose?

FS. I'll give her a temporary absolution until she can come in person. So, do you know where she could be?

Thus, Esperanza obtains what she wants: absolution for her daughter and continued encouragement to seek out Blanca. By insisting that the Church protect Blanca as best it can in these circumstances, Esperanza, like Dionisia, places a greater emphasis on pragmatic applications of faith than on dogmatic instructions. Meanwhile, Father Salvador, obviously interested for his own reasons throughout, manages to stay updated on Esperanza's mission.

It is not until Esperanza sets off for Tijuana that the film builds largely in chrono- 
logical time. As Esperanza leaves behind the confessional, her story progresses linearly, until she checks in with Father Salvador on the phone. During this call, the pattern of the compulsion to seek approval and forgiveness through a priest repeats itself. Additionally, the audience learns information that had been withheld from them prior to her phone call. This continues to privilege the confessional (albeit metaphorically) as the site of knowledge. In the conversation, after they greet each other, Esperanza butts her head up against the rules of the Church and has to consider how to work around them to attain what she needs:

E. A lot has happened, Father. I need to confess.

FS. You know you can't confess over the phone. More so if it's long distance.

E. You and your rules! What if I call it a confession and you call it a confidence?

FS. All right, go ahead.

At this point, she can tell him about her recent escapades, which include working as a prostitute in a Tijuana brothel where she believes there are young girls. Fortunately, a wealthy patron has decided to keep her exclusively for him, so she is not sure if she is really behaving as a prostitute. Of course she is, but like Dionisia, there are times when laws must be broken, both civil and religious. She says:

E. I just do things with him, but I don't know if they're sins.

FS. If you feel a need of repentance, then it's a sin. If not, it's not. You'll be able to tell.

This is an interesting twist, as Father Salvador explicitly leaves self-judgment to her own conscience. As Esperanza has justified her behavior because she was called by a saint to save her daughter, she is granted permission to trust herself to know if she is sinning. Dogma has been abandoned in favor of a "making do" attitude.

After this phone conversation, Esperanza continues on her journey entirely without returning to consult Father Salvador. She does try at one point, when she cannot reconcile what she believes two different saints are telling her to do: St. Jude still wants her to find her daughter, but St. Anthony appears to have found Esperanza a new love. Esperanza, like Dionisia, has created her own sort of altar to her personal saints, to which she turns in times of need. During this crisis, she tries to call Father Salvador but phone rings and rings; she hangs up and has to figure it out for herself - which she eventually does. Interestingly, when she returns home, just before the resolution of the film, she does not jump immediately into the confessional when offered the opportunity. Rather she prays to the saints and eventually finds the answer she was looking for, in her home no less. Armed with Father Salvador's comforting words, "Our Father will never abandon you," and hauling with her the piece of the wall on which her deceased daughter appeared to her and comforted her, Esperanza sets out again, this time at peace with her self and her beliefs.

As demonstrated by their stories, Esperanza and Dionisia have very little in common on the surface. Their immediate conflicts are different, yet their strategies for solving their respective problems are not as far apart as they might seem. They both continually negotiate in personal ways their participation in the rites of the Church. They both develop relationships with the priests of their parish, defined by 
their subordinate power status. And, ultimately, both women turn to a combination of Church-dictated expectations with self-reliance and individualized faith. The message can be read as a split between masculine and feminine approaches to obeying authority: Padre Amaro and Father Salvador (men and representatives of the Holy Church) purport to live by the canon of the Church, by dogma and by established rules, whereas Esperanza and Dionisia both practice a much more pragmatic approach to those expectations. In part, their dissent must remain somewhat "invisible" to the Church; this is why Dionisia hides spitting out her communion, and why Esperanza pushes forward according to her own imperatives and only afterwards seeks forgiveness. The question then becomes, why are these articulations of transgression appearing in contemporary cinema? What is gained by specifically presenting women and their actions in this setting, namely within the purview of the Church while behaving in contradiction of "the rules" established by the Church and by society?

\section{Official Histories: La Virgen and La Revolución}

The answer, as to be expected, takes some unraveling. First and foremost, this analysis is predicated on the perspective that the reality of contemporary Mexican life is one of contemporaneousness - that is a world where the past and the present are visible in daily life, whether in culture, ritual, landscape, or buildings, etc. Among others theorists, Nestor García Canclini's work on hybridity stands out, ${ }^{9}$ especially as it demonstrates that to interpret texts requires a willingness to explore the multiplicities of Mexican history that coexist in the present and are constantly recalled in cultural forms. Analyses of women in Mexican films reveal recurring figures, caught in negotiating their identity within the frameworks of the family and the nation. As outlined by film scholar Charles Ramírez Berg, they may occur on a spectrum of virgin/Virgin ${ }^{10}$ to whore, or said another way, along the long-held traditional binary of suffering mother to prostitute. Attempts to move out of stereotypical and limiting roles, at least for now, still have to deal with the heritage left by Mexico's cultural conceptions of women as confined to those social roles. ${ }^{11}$

Dionisia and Esperanza do not exactly fit into these categories, but rather their characterizations combine or confound them. For example, to some extent Dionisia lives outside society, but she is neither a prostitute nor a madwoman. For her part, Esperanza is a suffering mother as a result of Blanca's death, and not because she has sacrificed her happiness to the burden of childrearing and wifely duties; Esperanza is a prostitute but not really a prostitute; and in the end, she moves beyond the dichotomy of Virgin/whore by embracing her new love according to her own definition of what is sin and what is not. Dionisia and Esperanza both survive, albeit in their own ways, the action of the films without punishment, confinement, or otherwise descending into madness. Dionisia's and Esperanza's actions certainly stand as direct challenges to the Church, but by extension they can also be seen as statements of resistance against the State. Most obviously, Dionisia defies abortion law, and Esperanza defies immigration laws (she spends time in Los Angeles illegally) as well as prostitution laws. However, the films' potential to destabilize the Church and State, and much that they uphold as truth and rule of law, go far 
beyond these literal readings. To accomplish this, it is first necessary to consider the dominant rhetoric of Church and State within Mexico.

The master narratives of Church and State within Mexico are complex, and both are tied to myths of nation formation. The Church's dominant myth is based on the Virgin of Guadalupe, a relatively old legend with its origins shortly after the Spaniards' arrival in Mexico. At the time, the Church and the Holy Office of the Inquisition were intimately wrapped up in determining how to respond to the cult of worship surrounding the appearance of the Virgin. However, as she reportedly appeared to an Indian, Juan Diego, her legend was so warmly embraced by the native populations that her status as the mother of the new Mexican peoples has elided the more nefarious aspects of what Serge Gruzinski has called "ecclesiastical strategy" in the manipulation of the mythology (104). What the myth has served to accomplish in the long run is to legitimize the mestizo offspring of the Conquest and facilitate their adoption of the messages of Christianity. In his work on archetypes that influence Mexican film, Ramírez Berg discusses the Virgin, with quotes from Eric Wolf's work on the Virgin as Mexican national symbol:

The myth appealed to "the large group of disinherited who arose in New Spain as illegitimate offspring of Spanish fathers and Indian mothers, or through impoverishment, acculturation, or loss of status within the Indian or Spanish group." As time went by, the Virgin of Guadalupe myth assured the growing number of Mestizos a place in the hereafter as well as a "place in society here and now." (57)

Significantly, the myth of the Virgin also helps displace the history of La Malinche, one of the most pervasive symbols of indigenous violation by the Spanish. Even though La Malinche was sold into slavery to the Spanish, she served as their interpreter and is also considered the traitor of her people because she gave birth to Hernán Cortés' children, symbolically the first mestizos ${ }^{12}$ In this move, namely that the Virgin of Guadalupe redeems her children from the violation of the Conquest, the myth also displaces the role of the Church (i.e. the Holy Office of the Inquisition) in that subjugation. It is not difficult to understand why, collectively, indigenous peoples leaned towards identification with the Virgin as spiritual mother and patroness in times of need. The Church, for its part, undertook many concerted efforts to establish the purity of the legend and foster the cult of this national myth of origin, resulting at least for now in the Virgin that is honored as patron saint not only of Mexico but also of the Americas. That the Virgin of Guadalupe originated in Mexico, however, has tied her to Mexican Catholicism and devotion like nowhere else.

Although the Spanish Crown conquered the New World in the name of a State ruled by the Church, that complicity of rule began being challenged very shortly after Mexico declared itself an independent nation. By 1857, the Constitution provided for a separation of Church and State that included confiscation of church properties. Under Porfirio Díaz's rule (1876-1910), in adherence to a positivist doctrine, the Church and State were further at odds, with the State instituting civil marriages as law and nationalizing any properties still in Church hands. Persecution of priests and other professed Catholics was commonplace. By the time the Mexican Revolution began in 1910, socialist thought was taking hold and, as a result, the Church was still under persecution by the State (Dussel 103). Over time, and in part 
due to the overwhelming effectiveness of the conversion of the indigenous inhabitants of Mexico, the Church has regained some political footing. Even with the Catholic Church pushed to the background officially, it could never be ignored, not with the numbers of its members and not with the Basilica to the Virgen of Guadalupe established for centuries in the nation's capital.

Nonetheless, the State in Mexico has its own mythology of national identity, long promoted in the rhetoric of the Partido Revolucionario Institucional (PRI), the dominant party of Mexico from 1929 to the present. ${ }^{13}$ The new Mexican State traces its origins to the Mexican Revolution. In her article on women and melodrama in Mexican film, Ana López explains how the Revolution promised the workers a transformed nation:

[T] he revolution changes the nature of public life, mobilized the masses, shook up the structures of the family without changing its roots and, as Carlos Monsiváis says, "served as the inevitable mirror where the country recognized its physiognomy." The revolution may not have "invented" the Mexican nation, but "its vigor, for the first time, lent legendary characteristics to the masses that sustained it." In other words, the revolution created a new class (the new urban poor soon to be a working class) whose willpower, roughness, and illiteracy became instantly visible in the formerly feudal national landscape. (152)

In this rendition of national formation, the workers were the revolutionaries, the masses that had risen to overthrow the tyranny of dictatorship. Under the new social organization, there would be a middle class, and new opportunities for all Mexicans. For the patriarchy of the Church, however, the State simply substituted its own brand of patriarchal order. Women were pushed to the background, in that their role was to be pure and saintly, and to uphold "the fathers' law" (López 15253). The idea that the nation (or at least a "new" Mexican nation) was born of the Revolution is pervasive. The particular spin that the PRI has consistently put forth is that all Mexicans are the descendents of the revolutionary cause, and that, as descendents of the revolution, the PRI is the best party (hence the name: the Institutionalized Revolutionary Party) to continue to foster those ideals within Mexico. It is circular logic, but it worked for quite some time. ${ }^{14}$ All detractors aside, for decades, this was the official face of Mexican national rhetoric: a new nation forged from the courage of heroes, ready to take their fate into their own hands.

Not until recently has the State's façade been sufficiently challenged enough that the PRI has had to relinquish power to other parties. Furthermore, even as there have been instances in cultural production where the success of the Revolution has been questioned, suggesting only that the Revolution has failed is not the same as to provide any viable options on how to correct those failings and move forward (e.g., Ramírez Berg 201-10; Monsiváis 119). It is also not the same as challenging the claim that a "new" Mexico was born out of the Revolution-even if the ideals failed, they trace their origins to that point in history. By doing so they frustrate attempts to recall a history before the Revolution, for example the history of the Inquisition in shaping the nation, inasmuch as the society that existed then was ostensibly dismantled first by kicking Spain out in the 1800 s, and then finally by the revolutionaries. 
All in all, though they inform the present context of the films Santitos and The Crime of Padre Amaro, looking at these official histories is insufficient to explain the signification of Esperanza and Dionisia. While the argument can be made that both women strategically incorporate the Church into their belief systems, and manage to subvert power structures between themselves and the priests, this critique does not easily extend to a larger context, namely society as a whole, and both religious and secular aspects of being a part of that society. Critiques of the State are relegated to subplot threads in both instances. In Esperanza's case, she fights bureaucracy at every step of the way, as well as taking for granted that illegal trafficking of women is part of Mexican reality - the State is incapable of protecting its citizens. A similar conclusion results in Dionisia's instance: Amelia dies needlessly from an illegal abortion; drug cartels hold the local parish in its grip (and presumably local government); and corrupt priests face no challenge under any laws, civil or religious. However, moving beyond that which is hinted at in subplots in order to establish a deeper critique requires looking back into history for more than that which is sustained by "La Virgen" and "La Revolución."

\section{Rendering Women Invisible: The Inquisition and $18^{\text {th }}$-Century Mexico}

To establish the observed links between present and past, reenacted by Esmeralda and Father Salvador, and Dionisia and Padre Amaro, most resonant are the Church's dealings with women in dialogue with their confessors and/or with the Tribunals of the Inquisition, especially within the Mexican system of the 1700s. The back-story, however, begins when the Spanish Crown formally established the Mexican Inquisition in 1570 (Roth 210). As part of New Spain, the Mexican branch took many of its cues from Spanish Inquisitorial process and history. As best as they could, the agents of the Church tried to apply the logic of the Old World to the New, rooting out anyone who was not a true Christian. Understandably, their methods were not without problems.

In terms of investigating women during the $16^{\text {th }}, 17^{\text {th }}$, and $18^{\text {th }}$ Centuries, much focus was on curtailing any individualistic religious practices. By the $1600 \mathrm{~s}$, the Spanish Inquisition was investigating and persecuting mystics, with severer punishments handed down to those who refused to repent of their crimes. ${ }^{15}$ With the papal bull of 1634, the signs formerly read as divine possession and mysticism were no longer interpreted by the Church hierarchy as holy; they were instead signs of mental illness or demonic possession (Sluhovsky 163). One result of this change in perspective was that, leading up to the 1700s, women were accused of eliciting undue attention with their visions and mysticism (Christian 197). In addition to attempting to rid the New World of Jews and Heretics, often ones being chased for having escaped persecution in Spain and Portugal, a major concern for Inquisitors were subjects who practiced any sort of religious rite/ritual not overseen by the Church. As Jean Franco clearly demonstrates in her analysis of women within the convents of the $17^{\text {th }}$ Century, one of the primary functions of the priest-confessor relationship was to strictly delineate who had the power to interpret religious visions, where women's authority to "speak" of their visions was ultimately only acceptable through a process by which the priests edited the writings that the nuns produced under duress. ${ }^{16}$ Women's "knowledge" of their own fantasies and expe- 
riences was insufficient for Church authority - all writing was subject to interpretation for spiritual guidance under the rule of patriarchal law.

In the background of the events of the Inquisitorial Centuries, it is important to remember that women's role in the service of Church and husband was increasingly under the purview of dogma. As if it were not enough to deny women agency in religious settings, they were also more and more scrutinized even in their domestic behavior. Formally, in the $16^{\text {th }} \mathrm{C}$., the Council of Trent:

set firmly in place tenets that promoted obedience, humility, and service as ideals for women. [. . .] Whether in or out of the convent, women faced standards for behavior which emphasized submission to male authority and celebrated the ideals for women which the visual arts reinforced in images of the penitent Magdalen and Mary as sorrowing mother or the Immaculate Conception. Enclosure extended throughout society, sealing women in their homes, nuns in convents, and even prostitutes in brothels.(Giles 10)

Of course, cases demonstrate that women found their ways to rebel; however, increasingly this meant taking shelter in the very places in which they were confined, with limited capacity to speak or determine their public positions. ${ }^{17}$ While it is true that by the 1700s, as in Spain, Mexican authorities tended to treat women's cases and their "errors" more leniently, people were still bringing denunciations of heretical beliefs and specifically women's witching practices forward. In these cases, patterns emerge that provide insight as to what voices mattered to the official discourse of the time.

Notably, the lay cases are dominated by folk spirituality and accusations of witching - often treated as one and the same-yet are not limited to these practices. ${ }^{18}$ Ruth Behar's work has demonstrated that by the 1700 s, witchcraft generally did not provoke Inquisitorial wrath or even interest. Instead, the Church treated instances as ignorance rather than heresy: "The confessions and accusations of love magic and sexual witchcraft that people brought to the Inquisition, both in Spain and Mexico, were placed in the category of 'superstition' and dealt with leniently, for the most part" ("Sexual Witchcraft" 183). Ultimately, Behar states, the Inquisition:

viewed women's power as illegitimate in the sense that it was a delusion and therefore not really a form of power at all. By thus devaluing the discourse of women's magical power, not taking it altogether seriously, the Hispanic religious élite trivialized and denied what on the local level was viewed as a source of power for women.(184)

According to Behar's research, there are two general instances in which a woman's case might be more worthy of Inquisitorial attention: first, if the witchcraft concerned or contaminated the elite ("Sex and Sin" 50); second, if the accused were unrepentant. Behar concludes: "The outcome of a case hinged less on the question of whether a person was guilty or not guilty, than on subtler distinctions between 'repentant and unrepentant sinners, between accidental and deliberate sinners, between knaves and fools"" ("Sex and Sin" 36; "Sexual Witchcraft" 183). ${ }^{19}$ In other words, if a person was willing to turn away from error-i.e. repent and not speak of it again - the Inquisition could consider its task complete. Punishments reflected 
this, for rather than handing out relatively serious punishments even up to death, as had been common in earlier years, women's sentences included forms of banishment from public life, comparatively lenient lashings, confinement to or service in "Women's Hospitals," and rigorous confession schedules. ${ }^{20}$

During the Mexican Conquest, indigenous women were apparently unable to sufficiently disrupt colonial rule enough to be feared by authorities. However, this does not mean that, after the Mexican Tribunals had seemingly given up on rooting out idolatry and superstitions from the lower classes, fear was not still propagated locally by folk beliefs and "witching" practices. Cases demonstrate that, still during the 1700 s, priests were hearing confessions and denouncements and sending some of the accused and accusers to the Inquisition. In fact, many of Behar's cases demonstrate men's fear of women's witchcraft, both with respect to believed bodily harm and with respect to perceived disruption of social order. Even if the Inquisitors were not worried about women taking power away from them, men at the local level still feared it. For example, José de Ugalde denounced his wife for making him "stupid" and incapable of beating her (Behar, "Sexual Witchcraft" 179). Manuela de Bocanegra, a mulatta slave, was accused of ensorcelling her master, Fray Diego, even to the point of feminizing his body (195-97). Other cases reveal local instances of concern about women having the power to overturn traditional marital or confessor-penitent relations. ${ }^{21}$ None of these cases seems to have alarmed anyone outside the local setting, but certainly must have caused disturbances within the home if not within the community.

In addition to fear on the part of the men, whose gender privilege was being challenged, women's testimonies also reveal fear, as they attempted to negotiate between folk remedies for their miserable positions and the ever-judging eye of the Church. Essentially, fear inspired by the priests must be to blame for much of the self-denouncing that took place in the confessional. To digress briefly, shortly after the descent of the Spaniards on the New World, the Church considered its primary role there to be a (re)education of the indigenous population in order to save their souls, as well as tracking down non-Christians who had immigrated to avoid persecution. As mentioned previously, the priests themselves were trying as best as possible to carry out the mandates of Church canon and the Papal Bulls, with respect to the native populations and also the not-so-faithful European colonials. As a result, the Church's punishments were initially very harsh for both men and women. Women were victims, alongside men, of horrific prosecution if they were suspected of being Judaizers or heretics. ${ }^{22}$ Women in cloisters were also subjected to accusations of heresy or demonic seduction should they stray too far from accepted teachings (e.g., Holler 216+). If unrepentant all of these women, across class and race, were subject to harsh treatment under the Inquisition.

Behar establishes this aspect of patriarchal order in her articles, with respect to the longer-term effects of correction by the Church. By the 1700s, where women had internalized the Inquisition's mandates of behavior such that they could not reconcile contradictions between Catholic doctrine and the potential uses of folk remedies and witchcraft, they often ended up curtailing their own powers out of self-hatred instilled by indoctrination (Behar, "Sexual Witchcraft" 186). This phe- 
nomenon deserves attention briefly as an expression of women's responding to the imposed power of the Church into their domestic lives. As members of the faithful, women were expected to confess sins, but it becomes evident through some of the records that some women confessed activities because they were not sure if they had sinned or not. The women apply a sort of "better safe than sorry" approach to their relationship with their spiritual advisors. While sometimes the results seem relatively harmless for the women, at other times the process reinscribed their powerlessness. A significant portion of the sexual witchcraft was practiced not only to curtail their men's extra-marital sexual activities, but also to keep the women themselves safe from harm. José de Ugalde's wife, for example, was reportedly using her magic to keep from being beaten ("Sexual Witchcraft" 50). For many women, renouncing their folk practices certainly reinstated "normal" marital relations, including beatings.

Interestingly, as events reach the close of the 1700s, it appears that even if women felt compelled to speak up, or were denounced by their male counterparts, local clergy were beginning to ignore the rumors and evidences of witchcraft in their midst, as ordered by the Church hierarchy (e.g., Behar, "Sex and Sin" 50). The lower classes, as long as they did not interfere with the elite, were to be left to their own devices and silenced publicly if maleficium were brought up. In the wake of the Inquisition turning a deaf ear, the folk practices - which had frightened enough people at one time to reach the official documents - were officially silenced in public discourse. Women were told at every level, within Church boundaries, that their witchcraft was not powerful enough to merit attention, in fact that it was delusional. Notably, by the 18th-Century, women's pacts with the Devil were linked with maleficium and hence not treated as conscious heresy, whereas men's pacts still tended to be regarded as self-conscious heresy ("Sex and Sin" 43). Women seem to be treated as only receivers of the faith, expected to act in humility with respect to their husbands and the Church; they were treated as easily deceived but easily penitent and correctable as well.

Case after case reveals women who were not treated in the system as if they had the capacity to make Devil pacts or profess beliefs counter to the official except through delusion or weakness. Prosecutors and defenders alike refer to women as superstitious and easily misled, as defenses like Maria Guadalupe Rivera's on the grounds that she was penitent, that her delusions were because she was a woman, (and therefore they are not truly heresy, just errors), that she had been ill since very young, and that she was a good person, even a good Catholic (and therefore her errors are not from malice or evil) amply illustrate (AHN Reel 8, Leg. 1730, Doc. 4). To push this further, women were not permitted to speak their faith or work out their salvation in the ways that men were. Men's heresies were treated harshly, but as the products of humans capable of rationally receiving and understanding truth.

These conclusions are based on interpretations of documents as representative of the official position of the Church. However, the documents also provide another view beyond official ignorance of maleficium, demonstrating that despite the Church hierarchy's stance the legends of the curanderas and hechiceras persisted. Even while the Inquisition attempted to silence these women's practices officially, men- 
and even men in the Church - still turned to them for help at certain times. Men who believed themselves to be bewitched by folk practices actually sought out women with folk wisdom to cure them. From available records, it is clear that they denounced harmful effects or results of bewitching in hopes of receiving intervention from the Church, further ensuring that women's visibility within this framework was limited to the result of negative social behavior. Men were not seeking action against curandera practices, as long as they cured and did not result in further maleficium. In one case, Lorenzo Martinez Montañes sought out Bonifacia Miranda to remove a spell she had placed on him, and, when she cursed him further, he took it to a surgeon and only after that to his confessor (Behar, "Sex and Sin" 43). ${ }^{23}$ Examples such as this are not unusual, supporting the conclusion that it is when the magic did harm or could not help that men turned to ecclesiastical sources of power. Until then, they attempted to solve the problems from their perceived source: the women who cast the spells. Fortunately or unfortunately for the women accused, their so-called misbehavior preserved their histories. Silenced in public discourse does not mean that in private women's cultures and perceived influence did not live on. ${ }^{24}$

Franco's case study of Ana de Aramburu provides one final case by which to measure where Mexico's Inquisitorial processes were one the eve of Mexico's independence. In 1801, Ana was brought before the court as an "ilusa" or a "deluded woman" (55-56) Like some of the earlier cases, Ana's claims of extraordinary powers and her bodily performances of mysticism threatened clergy control at the very nexus of their power: the ability to establish and monitor divisions between truth and fiction (hence "good" and "evil") when it came to interpreting spiritual events (73-75). Ultimately, even if the Inquisitors did not see it this way, women were symbolically fighting for the right to use spirituality in a way that helped them make sense of their world, which did not often line up with the way the clergy deployed dogma. Significantly for the argument of this paper, a division of sorts arises, in which women like Ana turned to religion for practical applications, in women's terms, in the face of harsh containment by the logic and "surveillance" of the male-dominated confessional (Franco, esp. 69-70). It is not that women shunned religious participation, but instead that they sought ways to experience and practice religion that legitimized the female body and mind in spiritual activities. ${ }^{25}$ Additionally, even though women were not in charge of inscribing history, this case demonstrates that many were still taking part in alternative religious practices - "visible" women like Ana provide clues that many others existed under the radar of official discourse.

In summary, records and histories of the Inquisition in the New World indicate that the initial zeal of the Spanish crown to subjugate inhabitants in the name of saving their souls waned, in part because their efforts were working and the Church had substantial control over the peoples, and in part because the Church was recognizing the limits of its power even as "heretics" learned to keep their activities disguised or hidden from public view. During the entire time that Spain officially ruled Mexico before Mexico's independence in 1821, the Spanish branch of the Inquisition was alive and under the purview of the Spanish Crown. While different Spanish rulers gave the Office more support than others, the Office was not abolished until 1834 (Roth 267). What had begun as one of the most brutal systems of 
accusation, torture, and judgments between the highest of officials down to the lowest of subjects, slowly curtailed into a system largely reliant on Church instruction being handled locally between priest and congregant, within the rites of the confessional. Sins or errors did still move up the hierarchy, that is, if they were matters of the elite, sufficiently challenged Church authority, or affected governance.

As Mexico moved towards independence, the Church and the State were still working hand in hand to control the people who directly threatened their power. Father Hidalgo, whose words calling for revolution are now repeated every year from the national palace, was tried before the Tribunal "in absentia as a Deist, Atheist, Judaiser, Protestant, blasphemer and seducer" (Roth 261). He and other revolutionary leaders were judged under ecclesiastical law and then executed for crimes that today would more than likely be tried until civil law as treason. At that time in history Church and State were complicit in rule. In Mexico's case, three important factors resulting from this era must be remembered. First, the end of the Inquisition was not immediate, in that it had been wavering in power during its last few decades and there was always the threat of prosecution under the right circumstances; understandably, even when it was over it took years for the specter of the threat to wane (e.g., Roth 266). Second, in Mexico, even after Spanish rule was effectively over, its most powerful branch of social control was still in place - the Catholic Church. The discipline of that Church, although no longer specifically under the Inquisition, was still inquisitorial in nature and pervasive as it shepherded its people. Third, one of the most powerful instruments of control mobilized by the Church was to deny women authority and interpretive power, such that hysteria and ignorance were the domain of feminine space, and knowledge and truth were equated with patriarchal order.

\section{On the Reification of History and its Discontents}

Unraveling the questions of history and memory, whether cultural (or "collective") or individual is at the heart of many scholarly efforts. It is not my intent here to argue how these memories have been preserved across time, but rather to focus on how a certain linking of past and present, enacted in moments within these two films, can open a discourse surrounding the roles of Church and State in Mexico in sustaining official histories. The fact is that these representations do recur, and are only partially explicable within the models available which characterize women's roles in contemporary Mexican cinema. Looking for a deeper explanation of where these tropes might originate has the potential to destabilize normative treatments of women shaped by dominant rhetoric.

This essay's argument adds to the discussion of women in cinematic representation a woman who symbolically embodies relations of the past established by the Inquisition. She is a woman in negotiation of self-determination both inside and outside of the Church, and whose activities are mediated through the priestcongregant shepherding relationship. Dionisia's characterization as an hechicera, taking rites into her own hands, as well as her "outsider" status in the community, recall those women who kept their practices mostly confined to their homes. Her relationship with Padre Amaro has resonance with the accounts of women who 
were encouraged to keep quiet in public about their folk traditions, but to whom men turned when the Church could not provide remedy to a situation. Esperanza has organized her life (until the end of the film) around her relationship with Father Salvador as spiritual guide, continually checking her actions against dogma, even as she pushes the rules to meet her needs. Her questions bring to mind the women who sought confession in order to see if they had sinned or not-as well as perhaps testing the waters to see how far outside of the rules was too far. Father Salvador's frustration with Esperanza, while amusing within the diegesis, mirrors the clergy's eventual decision to ignore the practices they could not curtail.

This representation must be recognized for what it is: an enactment that bridges a past and present beyond those of official discourses. Because the judgment of women was and is conflated with sin and salvation, because the Church was established in Mexico as an arm of the Inquisition, and because that same Church as an institution has remained quite strong in Mexico (albeit without the tribunals), the Inquisition's foundational organization of social space and agency cannot help but have left its marks on future generations of believers. The fact that official histories elide this foundation should be interrogated. Reading Esperanza and Dionisia and their experiences as "signs" provides a lynchpin by which to disrupt the hegemonic sites of truth and knowledge which have been naturalized as the purview and domain of male power. The ability to redeploy a sign in the deconstruction of hegemonic "truths" is linked to the sign's history, above all to its context at the time of its creation. In Richard Terdiman's work "Deconstructing Memory: On Representing the Past and Theorizing Culture in France since the Revolution," he presents a compelling argument about how, especially since the $19^{\text {th }}$-century, the presentation and representation of history is wrapped up in the machinery of production, inasmuch as that machinery now creates material memories. These material memories, in their representations, tend towards the reification of history. His line of reasoning is constructive here, because his model demonstrates the importance of linking the present to the past through shared signs. In this case, of particular interest is to what ends the link of "priest to female parishioner relationship," as delimited above, may be theorized as a mediating sign across systems.

Significantly, Terdiman's argument about the dialectic of the sign asserts that dominant discourses, as well as their antagonisms, promote "a world defined by the untroubled stability and effectiveness of language itself" (26). To overcome this, it is necessary to consider the mechanisms that guard interpretations of representations of the past. Through its discourses, cultures achieve stability as they seek to attach certain meanings to certain references, without acknowledging the potential contained within other meanings' erasures. However, by turning to the memory model of "dialogism" or "intertextuality," where the sign stores and restores cultural memory - by being connected to both its present context and the multiplicities of its historical referents - a transcendence of the either/or model of meaning is possible. Terdiman details:

The purpose of conserving what is overcome in the process of the dialectic is to prevent either of its terms from being transformed into its only term. Any such slippage into self-identity produces one of two polar hypostatizations: either of the present, 
of the "text" (in an abstracting and self-referential idealism), or of the past, of the "real object" (in a detached and inert materialism). [. . .] But sustaining the tension between its terms is crucial, in order to inhibit any cancellation of their contradictory energy. (29-30)

In order to be productive, and not slip into reification, "The dialectic must always both remember (conserve) and overcome (transform) its referent" (32). In this way, cultural memory is able to both recall the past and be better prepared to transform the future.

This is precisely the task here, to both recognize a source of the sign (here described as "the legacy of the Inquisition") and tie the remembrance of that sign's history to present contexts in order to prevent reification of social memory according to dominant traditions. To achieve this, and provide a viable critique of those institutions, the interpretation of the articulation of "woman priest" must move out of present-day considerations and Church/State rhetoric. It is a matter of no longer saying, "oh yes we all know about the Inquisition"- - as many studies do, inserting their words of lip service even as they then put forth the "Virgin" or the "Revolution" versions of history - but rather to consider, even debate, openly the ramifications of un-erasing that legacy. The first step in opening up the dominant discourses of national formation is to recognize in this sign of "woman priest" that the accumulation of the past (not just one symbolic event) has led to the present. In Mexico, the Virgin of Guadalupe and the Revolution certainly both inform presentday experience. However, in the past, civil and religious society were also forged and disciplined by the Inquisition, with subsequent ramifications into the present. This intervention into the reified versions of national identity open up the critique to discourses that have the potential to negotiate and possibly transform the Church/State/ Subject relationships as they exist in the present. Perhaps a central question to raise is: considering Mexico's histories, what forces will forge and discipline the present?

By taking on the formation of Mexico from a multiplicity of perspectives, the possibility exists to raise fuller critiques than those that are narrowly confined by Church and State "official" versions of history. From this standpoint, the films may be read as asking, "If women still fight similar battles for self-determination 450 years after the initial Conquest, how much have La Virgen and La Revolución really helped them?" Not only that, but certainly these films foreground how much the Church itself continues to inform the daily lives of Mexicans, even as the State has spent decades trying to dismantle and deny its influence. None of this can be explained fully by looking at only one version of history. An anchor in the history of the Inquisition negates (or at least seriously contests) the Church and State's disavowal of the trauma of national formation. And who can blame them? The Inquisition is, as slavery is in the United States, surely a blemish on the nation's past. But the fact that cultural representations recall Inquisitional order indicates that the wounds of the Inquisition still inform daily life, despite the Church's promise of a new spiritual mother, and the Revolution's promise of a new nation. Further, the films' characterizations allow for an intervention specifically at the site of the traditional subject formation of women by the Church which splits largely into a choice between being a wife (or nun) subject to patriarchal law, or existing in a 
space outside of marriage defined by tenuous secretive practices curtailed in public by patriarchal law.

It is fair to ask: why are such representations recurring now? To answer, it is necessary to consider the implications of Mexico itself in crisis. Beyond "the crisis" of the 1980s, ${ }^{26}$ much is in flux within Mexico presently. There is the question of how much various Free Trade Agreements will help or hurt the nation's economy and autonomy, as well change the nature of labor within Mexico and its diasporic communities. There is also the question of what the political landscape within Mexico will look like as the PRI negotiates its place within changing partisan affiliations, and even its political role as the Catholic Church regains some of its governmental foothold. Interestingly, Padre Amaro may even be interpreted as a warning against Church and State collusion in the wake of an openly Catholic president (Fox) leading the country. The question of the role of the Catholic Church is also pressing, as both Protestants and Mormons are growing in numbers. While they have a relatively small constituency compared to the 89 percent of the population who identify as Catholics, both Protestant and Mormons members tend to be more active in their Churches than Catholics (Jenkins 62-63, 66). This means that even with smaller numbers, a surge in their activities politically may have significant impact. With everything that Mexico has gone through, where is it going to go now? How will its people survive amidst these shifts?

The answer may be found in the sign that both remembers and overcomes its referent. The women Dionisia and Esmeralda represent a line of women, hundreds of years in the making, recognized for their ability to "make do" and to survive. They have learned to embrace the Church and acknowledge the State, but without strictly adhering to the rules or dogma that have little or nothing to do with their lived experiences. Their narratives both recall and supercede aspects of womanhood in Mexican cultural production. They are the source of hope for a transformed nation, yet they are not "Vírgenes" nor even wives. Despite not being stereotypically "pure" they are also not fallen women along the lines of La Malinche or the doomed prostitute. They are not the source of evil to be contained and purged. They are women who not only think for themselves, but act on it. A "new" Mexico could learn a lot from them-but will be unable to do so if it does not recognize the mechanisms by which "woman" as "illegitimate source of knowledge" was naturalized. To look back at women's histories short of the Inquisition is to miss the emancipatory potential of that legacy - it is to be left only with its organization of social space and liturgical "knowledge" and miss the fact that existence was not destined to be structured in that manner.

Although they are characters, interpreting Dionisia and Esperanza's praxis through this lens returns the issue of religion to the public sphere and reminds the State that it should engage with its people as descendents of both Church and State histories. Further, when those institutions are no longer working, it is time to turn to the people for regeneration. For ultimately, it is not institutions that must survive, but people. In Santitos and The Crime of Padre Amaro, the biggest "crimes" are that institutions no longer know how to (or are unwilling to act to) protect those they purportedly serve. Instead, people must step up to take care of each other. By 
claiming its buried histories and learning from its lessons, Mexico has the tools to reconsider its legacy and its future.

\section{Acknowledgements}

This paper incorporates the result of work overseen in different renditions by Dr. Mariah Wade, Department of Anthropology, Dr. Virginia Garrard Burnett, Department of History, and Dr. Janet Staiger, Department of Radio-TV-Film - all professors at the University of Texas at Austin. Each professor has provided invaluable insight along the way. Furthermore, versions of this paper have been presented in early stages at conferences, namely the Emerging Scholarship in Women's and Gender Studies, in Austin, Texas, 2004, and the Cultural Studies Association, in Tucson, Arizona, 2005. Feedback from those presentations, conversations with friends, and insight from the anonymous reviewer of this essay, have also helped shape the present arguments.

\section{Notes}

${ }^{1}$ This quote is reproduced from page 43 of the edition of The Malleus Maleficarum as listed in Works Cited.

${ }^{2}$ From this point forward, "the Church" refers to the Roman Catholic Church and its representatives. Unless stated otherwise, for simplicity "the Inquisition" refers to the Spanish Inquisition and its established Tribunals in the New World, with the acknowledgment that all of this activity blossomed out of the ground set by the Papal Inquisition.

${ }^{3}$ The interested reader may find Michel-Rolph Trouillot's thesis in the first chapter of Silencing the Past: Power and the Production of History, "The Power in the Story."

${ }^{4}$ All translations for both films are based on the subtitles provided. Clarifications and comments appear in brackets, as well as in notes.

${ }^{5}$ Accordingly, Dionisia uses the formal conjugations of verbs when addressing Padre Amaro ("Ud.," not the familiar "tú"). However, she also calls him "Padrecito," translated as "Father dear," which besides indicating a certain level of respect and affection for him, is also the diminutive form of "Padre."

${ }^{6}$ Linguistics makes this line difficult to translate in subtitles, but for those who speak Spanish, Padre Amaro is not stuttering here, he is actually distinguishing between "un doctor" (a male doctor) and "una doctora" (a female doctor), indicating that the gender of the doctor is not what matters to him.

${ }^{7}$ Also, even though Dionisia may not know it, the audience is aware that the defamation against which Padre Amaro preached earlier was actually based on truth. The priests were able to deflect the so-called lies because their author was not a member of the Church. Hence, even if Dionisia were to speak up, we can guess that she would be treated similarly, with perhaps the leverage of her syncretic practices used against her.

${ }^{8}$ I have the word "confessions" in quotes to signal that the consultation nature of the session generally takes precedence over the rite of confessing sins. In a couple of their meetings, Father Salvador seems to remember that he is supposed to 
assign penance, and he says, "Just is case, say five rosaries."

${ }^{9}$ In particular, Néstor García Canclini's work Culturas híbridas: Estrategias para entrar y salir de la modernidad helps to map some of the "múltiples lógicas de desarrollo" (the "multiple logics of development") that shape Mexico's ideas of itself and the modernities that do and do not exist within it.

${ }^{10}$ In other words, "virgin" as conflated with the spiritual icon the Virgin of Guadalupe, a particularly pervasive cultural phenomenon.

${ }^{11}$ Furthermore, at least in films until the early 1980s, women who attempt to live outside of patriarchally ascribed roles end up becoming crazy. Madness becomes the only alternative to conformity. For specifics on all these traditions, see Charles Ramírez Berg's book Cinema of Solitude: A Critical Study of Mexican Film, 19671983, chapters 4 and 5 .

${ }^{12}$ Because of their succinctness, and also because I do not develop this branch of the argument here, I recommend Ramírez Berg's section on La Malinche in his book Cinema of Solitude, 56-57, and Ana López's article “Tears and Desire," 150-51.

${ }^{13}$ This party has had various names, all aligned with the Mexican Revolution, until settling on PRI in 1946 ("Historia del PRI"). Under those names, one of its members held the office of president until Vicente Fox's election in 2000, clearly dominating Mexican politics throughout the twentieth century. The PRI's party has diminished over the years as local governments elected opposition members, but even with Fox as president the PRI is a daunting political force.

${ }^{14}$ Oppositional parties did not begin picking up steam until the 1980 s, and from the 1930s through the 70s, the PRI "regularly won 85 percent of the total vote" (Smith, qtd. in Rodríguez and Ward 3). This was in part due to election control and voting fraud, but also to a perception by the public that voting did not matter, as they were represented by the PRI, the party of the Revolution.

${ }^{15}$ Cecil Roth's chapter "Alarms and Diversions" in The Spanish Inquisition is especially informative on these accounts.

${ }^{16}$ See Jean Franco's chapter "Writers in Spite of Themselves: The Mystical Nuns of Seventeenth-Century Mexico" from Plotting Women: Gender and Representation in Mexico.

${ }^{17}$ Accounts abound of secret communities, Christian "convert" or "converso" parents cloistering their daughters to protect them against prosecution, large webs of donations by former Jews or Muslims to local parishes to try to protect their families, or systems within families and communities by which especially women (who were more out of the public eye in general) transmitted Muslim or Jewish traditions and history. A sample of articles may be found in Mary Giles' collection Women in the Inquisition, as well as Mark Meyerson and Edward English's collection Christians, Muslims, and Jews in Medieval and Early Modern Spain.

${ }^{18}$ I present histories dominated by cases collected and analyzed by Ruth Behar, as her work was the most relevant to my project and she provided specific cases as opposed to generalizations. The cases span Behar's arguments for the $18^{\text {th }}$-century treatment of women delving into sexual witchcraft, casting spells onto their lovers or otherwise being in league with the Devil. In the course of my research, I have supplemented Behar's framework with other cases, particularly cases from archival 
materials from The Genaro García Collection and the Archivo Histórico Nacional (Spain) available through the University of Texas Benson Latin American Collection. In the rolls from "AHN, Inquisición" that I have examined, the majority of the cases against individuals are against men, with only 5 of the 68 documents detailing crimes against individual women. The crimes against men are largely for polygamy or are against priests for solicitation or other crimes. Women are also on trial for multiple marriages; however, so far, they are the only ones to be on trial for the spells or pacts with the Devil. Witchcraft, especially as conflated with women's heretical behavior, is central to how women and priest relationships developed during these years. The AHN Reels are, for all intents and purposes, unindexed, so they are rich in material for scholarship.

${ }^{19}$ The quote within a quote is from E. William Monter, Ritual, Myth and Magic in Early Modern Europe (Athens: Ohio UP, 1983), as quoted in Behar, "Sex and Sin," 36 and Behar, "Sexual Witchcraft," 183.

${ }^{20}$ Examples for this may be found in trials as recorded in the Archivo Histórico Nacional (Spain), Reel 8, Leg. 1730, Documents 4, 12, and 28, and Reel 10, Leg. 1730, Document 44.

${ }^{21}$ An illustrative case is that of Maria Guadalupe Rivera whom Fr. Mariano Lederma denounced for various heresies, including having no sins to confess in the confessional. Professing a personal relationship with "Dios Niño Señor," she claimed not to need the protection of the sacrament of confession, "Secreto de Confesion [sic]," and, furthermore, she did not fear the condemnation of priests. This record is in the Archivo Histórico Nacional (Spain), Reel 8, Leg. 1730, Document 4.

${ }^{22}$ One of the more infamous examples is the Carvajal case. Luis Carvajal y de la Cueva was the Governor of Nuevo León. All of the women Carvajal brought with him to the New World - his mother, three of this sisters, and his niece-were targeted by the Inquisition for Judaizing during the years of 1596-1601. The women and almost his entire family were tortured and eventually burned at the stake; even Carvajal was punished for the crime of harboring Jews, namely his family, and eventually died in prison (Roth 212; Hernández 66-67).

${ }^{23}$ In another interesting case, Fray Diego - a man who claimed that spells cast by his slave feminized him - consulted Gertrudis, a curandera, who was unable to heal him. After Gertrudis was unable to offer any relief, he heard that she was a sorceress; Fray Diego ultimately decided that Gertrudis must have been a part of the initial unnatural illness. Only then did he seek the Inquisition's help ("Sexual Witchcraft" 198-99).

${ }^{24}$ See note 19.

${ }^{25}$ As an example, Franco's chapter "The Power of the Spider Woman: The Deluded Woman and the Inquisition" discusses the way in which blood rituals factor into women's spirituality, subverting the patriarchal characterizations of the menstrual cycle (72).

${ }^{26}$ Mexico and the word "crisis" seem to go hand in hand from the late 1960s to the present, it just depends on which crisis one wishes to discuss. In this case, I refer to the crippling devaluation of the peso that changed the face of wages and employment for Mexicans, which began in the late 70s but hit the hardest in the early to mid 80s. For an economic explanation and evaluations of its effects on 
Mexican society, I recommend Jeffrey Bortz's article “The Effect of Mexico's Postwar Industrialization."

\section{Works Cited}

Archivo Histórico Nacional (Spain), Inquisición. Procesos de fe: Méjico 16021805, Reels 8 and 10. Benson Latin American Lib. Collection, Austin, TX.

Behar, Ruth. "Sex and Sin, Witchcraft and the Devil in Late-Colonial Mexico." Frontiers of Christian Evangelism. Spec. issue of American Ethnologist 14 (1987):34-54.

- . "Sexual Witchcraft, Colonialism, and Women's Powers: Views from the Mexican Inquisition." Sexuality and Marriage in Colonial Latin America. Ed.Asunción Lavrin. Lincoln: U of Nebraska P, 1989. 178-206.

Bortz, Jeffrey. "The Effect of Mexico's Postwar Industrialization.” U.S.-Mexico Relations: Labor Market Independence. Eds. Jorge A. Bustamante, Clark W. Reynolds, and Raúl A. Hinojosa Ojeda. Stanford: Stanford UP, 1992. 214-34.

Christian, William A., Jr. Apparitions in Late Medieval and Renaissance Spain. Princeton: Princeton UP, 1981.

The Crime of Padre Amaro. Dir. Carlos Carrera. 2002. DVD. Columbia TriStar, 2003. Dussel, Enrique. A History of the Church in Latin America: Colonialism to Liberation. Trans. Alan Neely. Grand Rapids, MI: Eerdmans, 1981.

Franco, Jean. Plotting Women: Gender and Representation in Mexico. New York: Columbia UP, 1989.

García Canclini, Néstor. Culturas híbridas: Estrategias para entrar y salir de la modernidad. Buenos Aires: Editorial Sudamericana, 1992.

Giles, Mary E., introduction and ed. Women in the Inquisition: Spain and the New World. Baltimore: Johns Hopkins UP, 1999.

Gruzinski, Serge. Images at War: Mexico from Columbus to Blade Runner (14922019). Trans. Heather MacLean. Durham: Duke UP, 2002.

Hernández, Marie Theresa. Delirio: The Fantastic, The Demonic, and the Réel. Austin: U of Texas P, 2002.

"Historia del PRI." Partido Revolucionario Institucional. 04 July $2005<\mathrm{http}$ // www.pri.org.mx/estadetulado/index.html>.

Holler, Jacqueline. “'More Sins than the Queen of England': Marina de San Miguel before the Mexican Inquisition." Giles 209-28.

López, Ana M. "Tears and Desire: Women and Melodrama in the 'Old'Mexican Cinema.” Mediating Two Worlds: Cinematic Encounters in the Americas. Eds. John King,Ana M.López, and Manuel Alvarado. London: BFI, 1993. 147-63.

The Malleus Maleficarum of Heinrich Kramer and James Sprenger. Ed., trans., and introduction Rev. Montague Summers. New York: Dover, 1971.

Monsiváis, Carlos. "Mythologies.” Mexican Cinema. Ed. Paulo Antonio Paranaguá. Trans. Ana M. López. London: BFI, 1995. 117-27.

Meyerson, Mark D., and Edward D. English, ed. Christians, Muslims, and Jews in Medieval and Early Modern Spain: Interaction and Cultural Change. Notre Dame: U of Notre Dame P, 2000.

Ramírez Berg, Charles. Cinema of Solitude: A Critical Study of Mexican Film, 
1967-1983. Austin: U of Texas P, 1992.

Rodríguez, Victoria E., and Peter M. Ward. "Introduction: Governments of the Opposition in Mexico." Opposition Government in Mexico. Eds. Victoria E. Rodríguez and Peter M. Ward. Albuquerque: U of New Mexico P, 1995. 3-16. Roth, Cecil. The Spanish Inquisition. 1964. New York: Norton, 1996.

Santitos. Dir.Alejandro Springall. 1998. DVD. 20 ${ }^{\text {th }}$ Century Fox, 2003.

Sluhovsky,Moshe. "Spirit Possession as Self-Transformative Experience in Late Medieval Catholic Europe." Self and Self-Transformation in the History of Religions. Ed.David Shulman and Guy G.Stroumsa.Oxford: Oxford UP,2002. 150-70.

Terdiman, Richard. "Deconstructing Memory: On Representing the Past and Theorizing Culture in France Since the Revolution.” Diacritics 15.4 (1985): 13-36. Trouillot, Michel-Rolph. Silencing the Past: Power and the Production of History. Boston: Beacon, 1995. 